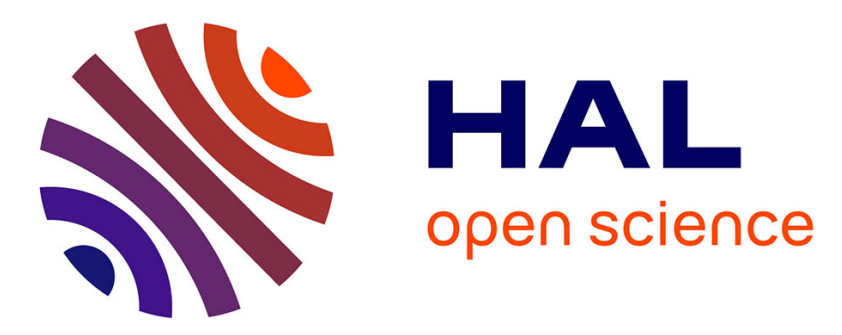

\title{
Less carbon emissions of wheat-maize intercropping under reduced tillage in arid areas
}

\author{
Falong Hu, Qiang Chai, Aizhong Yu, Wen Yin, Hongyan Cui, Yantai Gan
}

\section{To cite this version:}

Falong Hu, Qiang Chai, Aizhong Yu, Wen Yin, Hongyan Cui, et al.. Less carbon emissions of wheatmaize intercropping under reduced tillage in arid areas. Agronomy for Sustainable Development, 2015, 35 (2), pp.701-711. 10.1007/s13593-014-0257-y · hal-01284283

\section{HAL Id: hal-01284283 \\ https://hal.science/hal-01284283}

Submitted on 7 Mar 2016

HAL is a multi-disciplinary open access archive for the deposit and dissemination of scientific research documents, whether they are published or not. The documents may come from teaching and research institutions in France or abroad, or from public or private research centers.
L'archive ouverte pluridisciplinaire HAL, est destinée au dépôt et à la diffusion de documents scientifiques de niveau recherche, publiés ou non, émanant des établissements d'enseignement et de recherche français ou étrangers, des laboratoires publics ou privés. 


\title{
Less carbon emissions of wheat-maize intercropping under reduced tillage in arid areas
}

\author{
Falong Hu • Qiang Chai • Aizhong Yu • Wen Yin • \\ Hongyan Cui • Yantai Gan
}

Accepted: 26 September 2014 / Published online: 29 October 2014

(C) INRA and Springer-Verlag France 2014

\begin{abstract}
Intercropping is used to increase grain production in many areas of the world. However, this increasing crop yield costs large amounts of water used by intercropped plants. In addition, intercropping usually requires higher inputs that induce greenhouse gas emissions. Actually, it is unknown whether intercropping can be effective in waterlimited arid areas. Here, we measured crop yield, water consumption, soil respiration, and carbon emissions of wheatmaize intercropping under different tillage and crop residue management options. A field experiment was conducted at Wuwei in northwest China in 2011 and 2012. Our results show that wheat-maize intercropping increased grain yield by $61 \%$ in 2011 and $63 \%$ in 2012 compared with the average yield of monoculture crops. The intercropping under reduced tillage with stubble mulching yielded $15.9 \mathrm{tha}^{-1}$ in 2011 and $15.5 \mathrm{tha}^{-1}$ in 2012, an increase of $7.8 \%$ in 2011 and $8.1 \%$ in 2012 , compared to conventional tillage. Wheat-maize intercropping had carbon emission of 2,400 $\mathrm{kg} \mathrm{Cha}^{-1}$ during the growing season, about $7 \%$ less than monoculture maize, of $2,580 \mathrm{~kg} \mathrm{C} \mathrm{ha}^{-1}$. Reduced tillage decreased C emission over conventional tillage by $6.7 \%$ for the intercropping, $5.9 \%$ for monoculture maize, and $7.1 \%$ for monoculture wheat. Compared to monoculture maize, wheat-maize intercropping used more water but emitted $3.4 \mathrm{~kg} \mathrm{C}$ per hectare per millimeter of water used, which was $23 \%$ lower than monoculture
\end{abstract}

F. Hu $\cdot$ Q. Chai $(\bowtie) \cdot$ A. Yu $\cdot$ W. Yin $\cdot$ H. Cui $\cdot$ Y. Gan

Gansu Provincial Key Laboratory of Aridland Crop Science,

Lanzhou 730070, China

e-mail: Chaiq@gsau.edu.cn

F. Hu $\cdot$ Q. Chai $\cdot$ A. Yu $\cdot$ W. Yin $\cdot$ H. Cui

College of Agronomy, Gansu Agricultural University,

Lanzhou 730070, China

Y. Gan

Agriculture and Agri-Food Canada, Semiarid Prairie Agricultural Research Centre, Swift Current, SK S9H 3X2, Canada maize. Overall, our findings show that maize-wheat intercropping with reduced tillage coupled with stubble mulching can be used to increase grain production while effectively lower carbon emissions in arid areas.

Keywords Intercropping $\cdot$ Reduced tillage $\cdot$ Stubble retention $\cdot$ Soil respiration $\cdot$ Carbon emission

\section{Introduction}

Soils are the vital pools of carbon sequestration in the terrestrial ecosystems, and it is estimated that a global total of $2,500 \mathrm{Gt}$ of $\mathrm{C}$ is stored in soils, 3.3 times the amount of $\mathrm{C}$ stored in the atmosphere and 4.5 times the amount of $\mathrm{C}$ stored in biotic pool (Lal et al. 2004). In a global scale, a total of $75 \mathrm{Pg}$ of $\mathrm{C}$ has been emitted annually (Schlesinger and Andrews 2000), with a large portion of the emission from agriculture (Lal et al. 2004). Soil respiration, a pathway releasing $\mathrm{CO}_{2}$ from terrestrial ecosystems to the atmosphere (Raich and Tufekcioglu 2000), contains all $\mathrm{CO}_{2}$ fluxes originated from rhizodeposits, crop litter, and soil organic matter decomposition. A small change of soil respiration can have a large impact on $\mathrm{CO}_{2}$ concentration in the atmosphere ( $\mathrm{Lal}$ et al. 2004; Grace and Rayment 2000). Hence, soil respiration in agroecosystems is crucial in the global $\mathrm{C}$ cycle and $\mathrm{C}$ budget. The development of low-carbon agriculture systems to store as much $\mathrm{C}$ as possible in soils is considered an urgent measure in the 21st century (Fedoroff et al. 2010). A key strategy in reducing $\mathrm{C}$ emission from agricultural soils is to adopt improved farming practices in crop production (Gan et al. 2011b), such as the use of conservation tillage and intercropping (Fig. 1).

Conservation tillage is increasingly used in crop production due to their environmental advantages over traditional moldboard plow systems. Studies have shown that reduced tillage 
Fig. 1 Wheat/maize intercropping system tested at Wuwei experimental station, China, at a early co-growth period, b late co-growth period, $\mathbf{c}$ after wheat harvesting with stubble standing, and $\mathbf{d}$ after wheat harvesting with stubble mulching
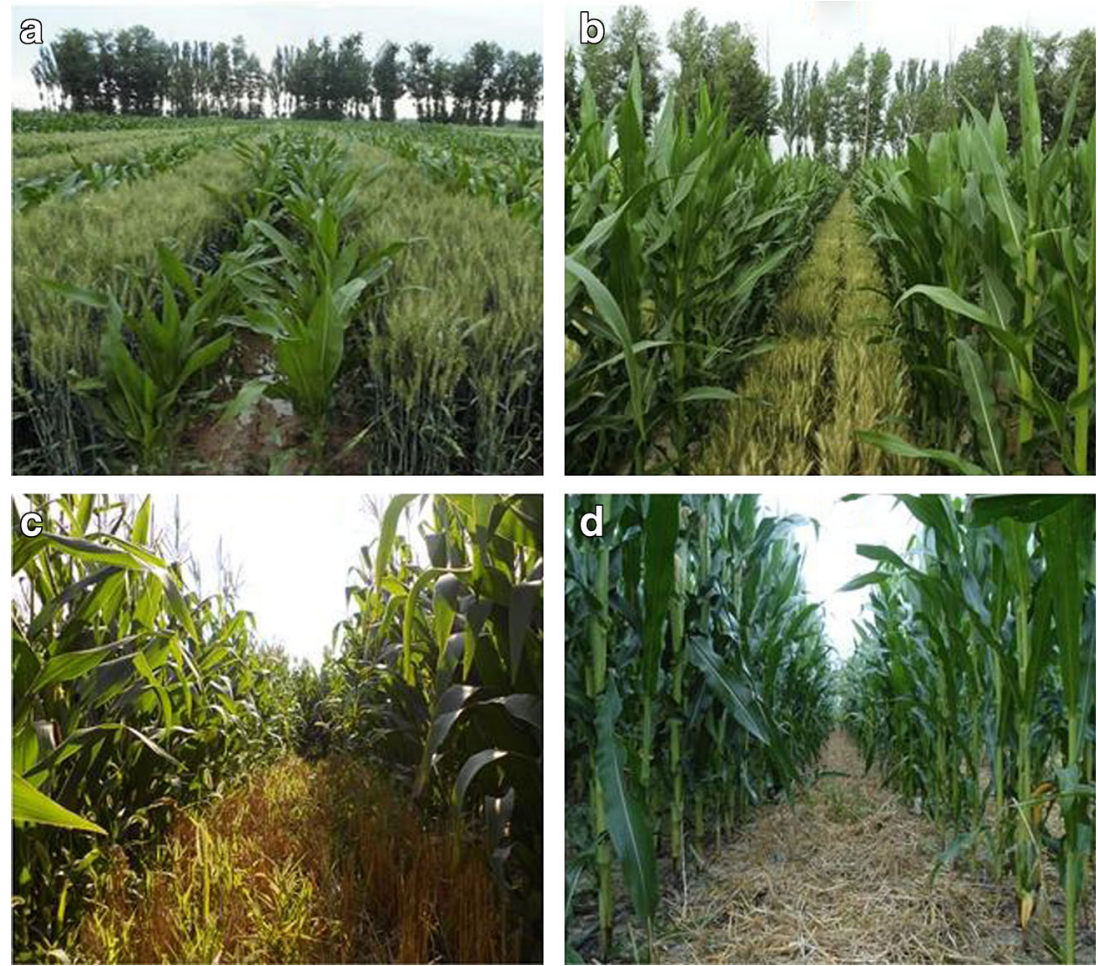

decreases soil disturbance (Alletto et al. 2010), inhibits soil microbial activities, and lowers $\mathrm{CO}_{2}$ emission from the soil (Boeckx et al. 2011). Furthermore, less disturbance to the soil due to reduced tillage in combination with crop residue retention on the soil surface has the potential to lower the emission of $\mathrm{CO}_{2}$ (Fuentes et al. 2011). However, most of the published studies are concerned on monoculture crops, i.e., sole cropping such as maize (Zea mays) and wheat (Triticum aestivum), and less attention has been paid on intercropping systems.

Intercropping has been widely adopted in many parts of the world as a means of increasing crop productivity (Chai et al. 2013), aiming at closing yield gaps between current crop yields and their potentials (Mueller et al. 2012). Also, cropping intensification is recognized as a key farming strategy in reducing global warming potential (Gan et al. 2012). The adoption of intercropping has significant advantages on carbon sequestration than conventional sole cropping (Asgedom and Kebreab 2011; Gan et al. 2011a). For example, maize-soybean (Glycine $\max$ L.) intercropping (Dyer et al. 2012) and maize-wheat intercropping (Beedy et al. 2010) enhance soil carbon sequestration and reduce carbon emission significantly compared to the corresponding monocultures.

In the Hexi Corridor of northwestern China, a typical oasis agricultural region, water availability is extremely low, with less than $150 \mathrm{~mm}$ of annual precipitation but with greater than $2,400 \mathrm{~mm}$ of annual evaporation (Chai et al. 2013). One of the effective strategies in conserving soil moisture in this area is to reduced tillage coupled with stubble retention. Crop residues on the soil surface form a barrier against evaporation and help maintain soil moisture. Also, the more the crop residues returned to the soil, the more the carbon is sequestrated because residues are precursors of the soil organic matter pool. However, more crop residue input in the soil may mean more $\mathrm{CO}_{2}$ emission when soil organic matter decomposition occurs. A sustainable strategy is urgently required to increase soil water conservation with stubble retention while reducing carbon emission. Here, we determined (i) the responses of grain yield, evapotranspiration, and carbon emission of wheatmaize intercropping to various tillage and stubble retention options and (ii) carbon emission per unit of water and the emission efficiency of intercropping systems in arid irrigation areas. We tested the hypothesis that reduced tillage in combination with stubble retention under wheat/maize intercropping could increase crop yield, conserve water, and reduce carbon emissions compared to conventional monoculture cropping systems.

\section{Materials and methods}

\subsection{Experimental site}

The field experiment was conducted in 2011 and 2012 at the Gansu Agricultural University Research Station, Wuwei, China $\left(37^{\circ} 96^{\prime} \mathrm{N}, 102^{\circ} 64^{\prime} \mathrm{E}\right)$. This station with altitude $1,506 \mathrm{~m}$, located in the eastern part of the Hexi Corridor of northwestern China, is at the temperate arid zone in the 
hinterland of the Eurasia Continent (Fan et al. 2012). The soil was an Aridisol (FAO/UNESCO 1988) with soil bulk density in the $0-1.1-\mathrm{m}$ soil profile averaged $1.4 \mathrm{~g} \mathrm{~cm}^{-3}$. Based on long-term (1960-2009) weather data, the solar radiation is $6,000 \mathrm{MJ} \mathrm{m}^{-2}$, annual sunshine duration is higher than $2,945 \mathrm{~h}$, and annual mean temperature is $7.2{ }^{\circ} \mathrm{C}$ with accumulated temperature above $0{ }^{\circ} \mathrm{C}$ higher than $3,513{ }^{\circ} \mathrm{C}$ and above $10^{\circ} \mathrm{C}$ higher than $2,985^{\circ} \mathrm{C}$, and the frost-free period is 155 days. Mean annual precipitation is $156 \mathrm{~mm}$, but the potential evaporation is $2,400 \mathrm{~mm}$. Total nitrogen $(\mathrm{N})$, phosphorous $(\mathrm{P})$, and organic matter of top $(0-60 \mathrm{~cm})$ soil is 0.78 , 1.14 , and $14.3 \mathrm{~g} \mathrm{~kg}^{-1}$, respectively.

\subsection{Experimental design and plot management}

In 2010, a pre-experiment was conducted to create proper wheat straw retention and tillage patterns that were prepared readily for the implementation of various treatments in the following years. In 2011, the four tillage and stubble retention patterns were implemented: (a) no till with $25 \mathrm{~cm}$ wheat stubble standing in the field (designated as RT1, stubble standing ), (b) no till with $25 \mathrm{~cm}$ height of wheat stubble chopped and spread evenly on the soil surface (RT2, stubble mulching), (c) tillage with $25 \mathrm{~cm}$ height of stubble was incorporated in the soil (RT3, stubble incorporated), and (days) conventional tillage (CT, tillage without stubble retention, i.e., all stubble was removed out of the field to mimic the local farming practice where stubble was transported to households for feeding and heating use). No-till and reduced tillage were represented by RT in the experiment. The wheat-maize intercropping was planted in strips with six rows of wheat alternated with two rows of maize in the set of $80: 80 \mathrm{~cm}$ in strip width. The different tillage and stubble retention patterns were applied to the wheat strips only, and all the maize strips were tilled. Conventional tillage without stubble retention was used as the control where a deep tillage $(30 \mathrm{~cm})$ in the previous fall was used for weed control and a pre-seeding rotary tillage was used for seedbed preparation. In both reduced and conventional tillage treatments, maize stalks were removed out of the fields for animal feeding. The sole maize and sole wheat were alternated among years, i.e., the plots grown with sole maize in the previous year were planted with sole wheat in the current year and vice versa. Similarly, in the wheat-maize intercropping, the maize strips in the previous year were planted with wheat in the current year and vice versa.

Due to low precipitation at the experimental areas, $150 \mathrm{~mm}$ annually, supplemental irrigation was applied according to the recommended irrigation schemes for the crops of study (Yang et al. 2011). All plots received an amount of $120 \mathrm{~mm}$ of irrigation in the previous winter just before soil freezing, and then, various irrigation quotas were applied at the different growth stages in the current year to satisfy the treatment requirements. A hydrant pipe system was used for irrigation, and a flow meter was installed at the discharging end of the pipe to measure and record the irrigation amounts.

Spring wheat (the cultivar Yong-Liang no. 4) was planted on 28 Mar. in 2011 and 19 Mar. in 2012 and harvested on 22 July in 2011 and 18 July in 2012, and the maize (the cultivar Wu-Ke no. 2) was planted on 17 Apr. and 20 Apr. and harvested on 29 Sep. and 30 Sep. in the 2 years, respectively. Plot size was $4.8 \mathrm{~m} \times 10 \mathrm{~m}$. Wheat and maize were alternated in 160-cm-wide strips with wheat strip ( $80 \mathrm{~cm}$ wide) consisted of six rows with a row space of $12 \mathrm{~cm}$, and maize strip $(80 \mathrm{~cm}$ wide) had two rows of maize with $40 \mathrm{~cm}$ interrow. Maize strips were mulched with plastic films at seeding, an innovative technology for boosting maize productivity in arid environments (Gan et al. 2013). Planting density was $6,750,000$ plants $\mathrm{ha}^{-1}$ for wheat and 82,500 plants ha $^{-1}$ for maize. The $\mathrm{N}$ rates to sole wheat and sole maize were 225 and $360 \mathrm{~kg} \mathrm{Nha}^{-1}$, and $\mathrm{P}_{2} \mathrm{O}_{5}$ rates were 66 and $158 \mathrm{~kg} \mathrm{P} \mathrm{ha}^{-1}$. For intercrops, each species received the same rate of fertilizers on a per hectare basis as the sole crops; i.e., the $\mathrm{N}$ and $\mathrm{P}$ rates were halved for each particular species because each species occupied one-half areas as in the sole cropping. All $\mathrm{N}$ and $\mathrm{P}$ were applied as base fertilizer to wheat, while maize received $30 \%$ of $\mathrm{N}$ as base fertilizer at sowing, $60 \%$ as topdressing at jointing, and the remaining $10 \%$ as topdressing at grain filling.

\subsection{Measurements and statistical analysis}

\subsubsection{Soil respiration}

Soil respiration was measured with a CFX-2 system (Soil $\mathrm{CO}_{2}$ Flux System, CFX-2, PP System Hitchin, UK) connected with a proprietary respiration chamber. Before measuring, all crop residues and other litters on soil surface were removed, and a hole with a diameter the same as the respiration chamber size was made on the maize strips in order to release the stored $\mathrm{CO}_{2}$ efflux, at least $12 \mathrm{~h}$ before the measurement. The chamber, with a sharp edging point at the bottom, was placed on the soil surface and then pushed to the depth of $20 \mathrm{~mm}$. Measurements were made at three places randomly selected in each plot, five values were recorded for each place within $180 \mathrm{~s}$, and the average value was used for each plot. For intercropping, measurements were taken for each of the intercrops by placing the instrument in the wheat strip and maize strips, and the averages of the two strips were used for a plot. The diurnal soil respiration was measured at 2-h interval from 8:00 am to 8:00 $\mathrm{pm}$ on the selected dates, and the seasonal measurements were started on $21 \mathrm{Apr}$. in 2011 and 22 Apr. in 2012, and the rest of the measurements were taken at 20-day interval from April to September in each year. 


\subsubsection{Evapotranspiration}

The evapotranspiration (ET) $(\mathrm{mm})$ was determined using water balance equation (Yang et al. 2011):

$\mathrm{ET}=P+I+\mathrm{WS}_{\mathrm{s}}-\mathrm{WS}_{\mathrm{h}}$

where $P$ is the effective precipitation ( $\mathrm{mm}$ ), determined by the US Department of Agriculture Soil Conservation Services method (USDA-SCS 1972), $I$ is the irrigation quota (mm), and $\mathrm{WS}_{\mathrm{s}}$ and $\mathrm{WS}_{\mathrm{h}}$ are soil water storage $(\mathrm{mm})$ at $0-1.2 \mathrm{~m}$ depth before sowing and after harvesting, respectively.

Soil water contents in the $0-30-\mathrm{cm}$ depth by $10-\mathrm{cm}$ increments were measured using the oven-drying method, whereas soil water in the $30-120-\mathrm{cm}$ depth by $30-\mathrm{cm}$ increments was measured using neutron probe (NMM 503 DR, USA). The average value of two intercrops was used for a plot.

\subsubsection{Grain yield}

All plots were harvested when plants reached the full maturity, and grains were air-dried, cleaned, and weighed for the yield of the sole and intercropped crops individually.

\subsubsection{Carbon emission and carbon emission per unit of water}

Carbon emission $\left(\mathrm{kg} \mathrm{ha}^{-1}\right)$ was estimated based on soil respiration $\left(\mathrm{g} \mathrm{CO}_{2} \mathrm{~m}^{-2} \mathrm{~h}^{-1}\right)$ using the following equation described by Zhai et al. (2011):

$\mathrm{CE}=\sum\left[\frac{\mathrm{SR}(i+1)+\mathrm{SR} i}{2}[t(i+1)-t \mathrm{i}] \times \frac{12}{44}\right] \times 24 \times 10$

where SR was the soil respiration $\left(\mathrm{g} \mathrm{CO}_{2} \mathrm{~m}^{-2} \mathrm{hr}^{-1}\right)$ measured at 20-day interval during the growing season and post-harvest period, $i+1$ and $i$ were the previous and the current sampling date, respectively, and $t$ was the days after sowing.

Based on the conception of water use efficiency, the term "carbon emission per unit of water $\left(\mathrm{kg} \mathrm{ha}^{-1} \mathrm{~mm}^{-1}\right)$ " was determined to describe the magnitude of carbon emission $\left(\mathrm{kg} \mathrm{ha}^{-1}\right)$ associated with per unit of ET $(\mathrm{mm})$ and defined as carbon emission during growing season divided by ET, as follows:

$\mathrm{WUE}_{\mathrm{CE}}=\frac{\mathrm{CE}}{\mathrm{ET}}$

where carbon emission (CE) is the carbon emission $\left(\mathrm{kg} \mathrm{ha}^{-1}\right)$ and ET is the evapotranspiration ( $\mathrm{mm}$ )

\subsubsection{Carbon emission efficiency}

There has been a concern that higher crop productivity may result in more carbon emission during the crop production. In order to quantify the correlation between grain yield and carbon emission, the term "carbon emission efficiency (CEE)" was created in the present study, which was expressed as follows:

$\mathrm{CEE}=\frac{\mathrm{GY}}{\mathrm{CE}}$

where grain yield (GY) is the grain yield $\left(\mathrm{kg} \mathrm{ha}^{-1}\right)$ and CE is the carbon emission $\left(\mathrm{kg} \mathrm{ha}^{-1}\right)$.

\subsubsection{Land equivalent ratio}

Land equivalent ratio (LER) is defined as the land area required by sole crops to produce the same volume of grain yield produced by intercrops. A value of LER $>1.0$ indicates a yield advantage of intercropping over sole cropping and vice versa. The ratio is calculated as follows:

$\mathrm{LER}=\frac{Y \mathrm{iw}}{Y \mathrm{sw}}+\frac{Y \mathrm{im}}{Y \mathrm{sm}}$

where $Y_{\mathrm{iw}}$ and $Y_{\mathrm{sw}}$ are grain yields of intercropped wheat and sole wheat, respectively, and $Y_{\mathrm{im}}$ and $Y_{\mathrm{sm}}$ are grain yields of intercropped maize and sole maize, respectively.

Based on the notion of LER, the $\mathrm{LER}_{\mathrm{CEE}}$ can be explicated as land equivalent ratio which counted on carbon emission efficiency.

\subsubsection{Statistical analysis}

Data were analyzed using Statistical Analysis Software (SPSS software, 16.0, SPSS Institute Inc., USA), and treatment effects were determined using the Duncan's multiple range test. Due to significant year $\times$ treatment interactions for most of the variables evaluated in the study, the treatment effect was assessed for each year separately. All significances were declared at the probability level of 0.05 .

\section{Results and discussion}

3.1 The seasonal variation of soil respiration

Soil respiration is one of the most useful tools for measuring $\mathrm{CO}_{2}$ fluxes from soils (Raich and Tufekcioglu 2000), and the 
quantification of soil respiration is linchpins in global carbon budget. Crop management practices such as tillage, cropping sequence, and intensity are the main factors affecting soil respiration (Sainju et al. 2006). In the present study, we found that the seasonal patterns of soil respiration was similar for various sole crops and wheat/maize intercrops, with the respiration rates peaked in late June, began to decline in early July, and then reached the lowest in September in both 2011 and 2012. However, the absolute value of soil respiration differed significantly between treatments (Table 1). Monoculture maize had the highest soil respiration among all cropping patterns evaluated in this study, with a mean value of $1.57 \mu \mathrm{mol} \mathrm{m}^{-2} \mathrm{~s}^{-1}$, which was nearly twice as high as intercrops (average $0.83 \mu \mathrm{mol} \mathrm{m}^{-2} \mathrm{~s}^{-1}$ ). Intercropping reduced soil respiration by an average of $50 \%$ in 2011 and $46 \%$ in 2012, compared to sole maize. The maximal rate of seasonal soil respiration of intercropping was 45 and $47 \%$ lower than that of sole maize in 2011 and 2012, respectively. The growth of maize in intercropping was partially impaired by interspecific competition ( $\mathrm{Li}$ et al. 2008), leading to a reduction of soil respiration.

Tillage and residue management are two major factors affecting $\mathrm{CO}_{2}$ emission from soils. Some studies reported that conventional tillage emitted more $\mathrm{CO}_{2}$ than reduced tillage as a result of soil disturbance from plough (Fuentes et al. 2011), whereas others found no differences between the two tillage practices (Elder and Lal 2008). Our result showed that reduced tillage decreased soil respiration and lowered $\mathrm{CO}_{2}$ emission compared to conventional tillage (Table 1). Maize monoculture with reduced tillage (average $1.51 \mu \mathrm{mol} \mathrm{m}^{-2} \mathrm{~s}^{-1}$ ) decreased soil respiration by $9 \%$ compared to maize monoculture with conventional tillage $\left(1.65 \mu \mathrm{mol} \mathrm{m} \mathrm{m}^{-2} \mathrm{~s}^{-1}\right)$. Reduced tillage with stubble mulching on the soil surface was most effective in lessening soil respiration among the three reduced tillage treatments. Compared to conventional tillage (as the check), wheat/maize intercropping with reduced tillage and stubble retention on the soil surface decreased soil respiration by $20 \%$ in 2011 and $12 \%$ in 2012. Among all the treatments evaluated in the study, the wheat/maize intercropping with applied stubble mulching under reduced tillage had the lowest soil respiration (Table 1). That was $21 \%$ lower than wheat/maize intercropping under reduced tillage with stubble standing in 2011 and $11 \%$ in 2012. Wheat/maize intercropping with reduced tillage and stubble incorporated in the soil achieved $16.6 \%$ less soil respiration than wheat/maize intercropping with conventional tillage in 2011, but none difference was found in 2012.

In the present study, the soil respiration under reduced tillage with stubble mulching was decreased by 17 to $20 \%$ over conventional tillage, suggesting that carbon dioxide emission can be reduced substantially by use of such reduced with residue retention in the production of field crops.

\subsection{Water consumption}

Averaged across 2 years, water consumption of wheat-maize intercrops ranged from 682 to $754 \mathrm{~mm}$, sole wheat from 378 to $416 \mathrm{~mm}$, and sole maize from 589 to $644 \mathrm{~mm}$ (Table 1). Generally, intercropping increased water consumption by $72 \%$ than sole wheat and by $22 \%$ than sole maize. However,

Table 1 Averaged soil respiration (SR), grain yield, and water consumption of wheat and maize in the sole and intercropped systems in an oasis region, in 2011 and 2012

\begin{tabular}{|c|c|c|c|c|c|c|}
\hline \multirow[t]{2}{*}{ Treatment } & \multicolumn{2}{|c|}{ Averaged SR $\left(\mu \mathrm{mol} \mathrm{m} \mathrm{m}^{-2} \mathrm{~s}^{-1}\right)$} & \multicolumn{2}{|c|}{ Grain yield $\left(\mathrm{t} \mathrm{ha}^{-1}\right)$} & \multicolumn{2}{|c|}{ Water consumption (mm) } \\
\hline & 2011 & 2012 & 2011 & 2012 & 2011 & 2012 \\
\hline \multicolumn{7}{|c|}{ Intercropping } \\
\hline RT1 & 0.94 & 0.85 & 15.83 & 15.61 & 752 & 676 \\
\hline RT2 & 0.75 & 0.76 & 16.17 & 16.05 & 736 & 670 \\
\hline RT3 & 0.78 & 0.82 & 15.57 & 14.95 & 756 & 685 \\
\hline $\mathrm{CT}$ & 0.94 & 0.87 & 14.70 & 14.36 & 771 & 695 \\
\hline \multicolumn{7}{|c|}{ Monoculture } \\
\hline RT1 & 0.94 & 1.63 & 6.70 & 13.05 & 414 & 591 \\
\hline RT2 & 0.77 & 1.34 & 6.86 & 13.25 & 404 & 579 \\
\hline RT3 & 0.87 & 1.56 & 6.50 & 12.16 & 423 & 595 \\
\hline $\mathrm{CT}$ & 0.93 & 1.65 & 6.39 & 11.65 & 424 & 592 \\
\hline$p$ value $^{\mathrm{a}}$ & $<0.01$ & $<0.01$ & $<0.01$ & $<0.01$ & $<0.01$ & $<0.01$ \\
\hline $\operatorname{LSD}(0.05)$ & 0.07 & 0.09 & 0.13 & 0.21 & 14 & 10 \\
\hline
\end{tabular}

$R T 1$ reduced tillage with stubble standing, $R T 2$ reduced tillage with stubble mulching, $R T 3$ reduced tillage with stubble incorporated in the soil, $C T$ conventional tillage without stubble retention

${ }^{\mathrm{a}}$ The $p$ value and the $\operatorname{LSD}(0.05)$ were for all the treatments in the column 
intercropping achieved an equivalent to or higher water use efficiency than sole maize due to greater grain yields (data not presented). All crops, i.e., intercrops and sole crops with reduced tillage, had lower water consumption than those under conventional tillage (Table 1). Intercrops with reduced tillage have the average water consumption of $748 \mathrm{~mm}$ in 2011 and $667 \mathrm{~mm}$ in 2012, which were, respectively, 3.0 and $2.6 \%$ lower than intercrops with conventional tillage. Moreover, wheat monoculture with reduced tillage decreased water consumption by $2.4 \%$ compared to wheat under conventional tillage.

Stubble mulching on the soil surface combined with reduced tillage had great benefits in reducing water consumption (Table 1). For intercropping, reduced tillage with stubble mulching system decreased water consumption by 4.5 and $3.6 \%$ in 2011 and 2012 compared to conventional tillage system. Whereas, intercropping with stubble standing in the field under reduced tillage or incorporated into the soil did not have any consistent influence on water consumption in either year.

\subsection{Yield response}

Mixed yields are the total yields of the two component crops, i.e., wheat and maize in the intercropping systems (Table 1). The land equivalent ratios of intercropping with the four different straw management options were all greater than 1.0. On average, intercropping increased yields by $61 \%$ in 2011 and $63 \%$ in 2012 compared to sole crops, and the intercropping with reduced tillage significantly $(P<0.05)$ improved the land equivalent ratio over conventional intercropping. These results indicate that the wheat/maize intercropping uses less land area to achieve an equivalent grain yield as sole cropping or producing more grains than sole cropping with the same land area.

Tillage with stubble retention had a significant $(P<0.05)$ impact on yields (Table 1). Intercropping with reduced tillage had an average grain yield of $15.85 \mathrm{t} \mathrm{ha}^{-1}$ in 2011 and $15.54 \mathrm{t} \mathrm{ha}^{-1}$ in 2012, an increase of $7.8 \%$ in 2011 and $8.1 \%$ in 2012, compared to intercropping with conventional tillage. Similarly, sole maize with reduced tillage (average yield $12.82 \mathrm{t} \mathrm{ha}^{-1}$ ) improved yield by $10 \%$ over sole maize with conventional tillage. Among the three conservation tillage treatments, reduced tillage with straw mulching on the soil surface achieved the highest yields (Table 1). In 2011, wheat/ maize intercropping under reduced tillage with stubble mulching increased yields by $9.9 \%$ than conventional wheat/maize intercropping; sole wheat under reduced tillage with stubble mulching increased yields by $9.3 \%$ than conventional sole wheat. In 2012, wheat/maize intercropping with reduced tillage and stubble mulching improved yields by $12 \%$ than conventional wheat/maize intercropping, and sole maize with reduced tillage and stubble mulching increased yields by $9 \%$ compared to conventional sole maize.

\subsection{Carbon emission characteristics}

\subsubsection{Carbon emission during growing seasons}

Soil C storage is usually determined by the balance between $\mathrm{C}$ inputs from crop residues and rhizodeposits and $\mathrm{C}$ loss through $\mathrm{CO}_{2}$ emission. Less carbon emission means more $\mathrm{C}$ sequestration in soils, thus providing adequate $\mathrm{C}$ resources for crop growth and mitigating greenhouse gas effects. The present research showed that wheat/maize intercropping emitted comparatively lower carbon, averaging $2,411 \mathrm{~kg} \mathrm{C} \mathrm{ha}^{-1}$ annually, which was $10 \%$ less than sole maize. This directly relates to lower soil respiration rate of wheat/maize intercropping system. Overall, intercropped maize emitted 26 to $50 \%$ more carbon than the intercropped wheat (Table 2), showing that intercropped maize greatly contributed to carbon emission in the wheat/maize intercropping system. Monoculture maize, however, emitted about $2,585 \mathrm{~kg} \mathrm{C}^{-1}$ annually, the highest among the planting patterns.

Reduction in soil disturbance combined with residue retention reduced the emission of $\mathrm{CO}_{2}$ compared with conventional tillage. On average, reduced tillage decreased $\mathrm{C}$ emission by $6.7,5.9$, and $7.1 \%$ for intercropping, sole maize, and sole wheat, respectively (Table 2). Wheat/maize intercropping with stubble mulching significantly $(P<0.05)$ lessened carbon emission by $10 \%$ over conventional tillage. Compared to conventional tillage, reduced tillage with stubble mulching or with stubble incorporated in the soil of maize monoculture decreased $\mathrm{C}$ emission by 14 and $5 \%$, respectively, and the two respective tillage managements on wheat monoculture decreased the emission by 6 and $8 \%$, respectively. In contrast to the two distinct tillage types, reduced tillage with stubble standing did not have a consistent effect on carbon emission, suggesting that stubble standing is an unsuitable type of straw management for this area. However, stubble mulching on soil surface or stubble incorporating into topsoil requires mechanical power, which may emit more carbon. More comprehensive analysis is needed to determine the effect of straw retention options on carbon emission in arid irrigation areas.

Our results indicate that the impact of intercropping with reduced tillage on carbon emission is significant. Interplant competition when two crop species are planted in strips and the "relay" growth of the two intercrops during the growing season contribute to the decreased carbon emission. Furthermore, crop residue retention on the soil surface influences soil temperature, 
soil moisture, and plant growth which greatly influences soil respiration. However, it is unknown whether or not those effects can be carried on year after year, as more residues are added to the soil with the conservation technology each year. Therefore, further studies on the correlation between the influencing factors and carbon emission are needed in this arid oasis area. Also, the complex agronomic operation of intercropping often requires more labor input or mechanical power than monoculture. Accordingly, some well-designed experiments may be needed to quantify carbon emission at a system level. Also, some systematic research on carbon footprint, defined as the total greenhouse gas emission per unit of grain produced (Gan et al. 2011b), may be required for accurately assessing the benefits of intercropping systems.

\subsubsection{Carbon emission per unit of water}

Water is the most important factor limiting crop production in the arid northwest China (Chai et al. 2013). Intercropping used more water but emitted less carbon (Table 2). To quantify how much carbon that plants emitted per unit of water used, we created the term "carbon emission per unit of water" in this study and determined the differences between the various cropping systems. Sole maize had the greatest carbon emission per unit of water used among all treatments, with a mean value of $4.3 \mathrm{~kg} \mathrm{C} \mathrm{ha}^{-1} \mathrm{~mm}^{-1}$ (Table 2). The adoption of wheat/maize intercropping $\left(3.4 \mathrm{~kg} \mathrm{C} \mathrm{ha}^{-1} \mathrm{~mm}^{-1}\right)$ reduced carbon emission per unit of water by $23 \%$ over sole maize albeit increased water consumption. Reduced tillage had average carbon emission per unit of water values of 3.3, 2.3, and $4.2 \mathrm{~kg} \mathrm{C} \mathrm{ha}^{-1} \mathrm{~mm}^{-1}$ for intercropping, sole wheat, and sole maize, respectively, which was 4.0, 4.7, and $5.3 \%$ lower compared to conventional tillage.

Among the three stubble retention treatments, stubble mulching reduced carbon emission per unit of water by $8 \%$ for wheat/maize intercropping, $10 \%$ for sole maize, and $9 \%$ for sole wheat, as compared with the other two stubble management options (Table 2). In comparison to conventional tillage, reduced tillage decreased carbon emission per unit of water by $10 \%$ for sole maize, by $6 \%$ for sole wheat, and by $9 \%$ for wheat/maize intercropping.

\subsubsection{Carbon emission efficiency}

The adoption of intercropping systems is an effective approach to increase crop productivity, reduce soil respiration, and lower carbon emission in arid lands (Qin et al. 2013). However, little is known about how effective this approach is in regard to increasing grain yield while reducing carbon

Table 2 Carbon emission during the growing season, carbon emission efficiency (CEE), and carbon emission per unit of water (WUE ${ }_{\mathrm{CE}}$ ) for various wheat/maize intercropping systems and the corresponding sole cropping in an oasis region, in 2011 and 2012

\begin{tabular}{|c|c|c|c|c|c|c|c|c|c|c|}
\hline \multirow[t]{3}{*}{ Treatment } & \multicolumn{6}{|c|}{ Carbon emission $^{\mathrm{a}}$} & \multicolumn{2}{|l|}{ CEE } & \multicolumn{2}{|c|}{ WUE $_{C E}$} \\
\hline & \multicolumn{3}{|l|}{2011} & \multicolumn{3}{|l|}{2012} & \multirow[t]{2}{*}{2011} & \multirow[t]{2}{*}{2012} & \multirow[t]{2}{*}{2011} & \multirow[t]{2}{*}{2012} \\
\hline & Maize & Wheat & Total & Maize & Wheat & Total & & & & \\
\hline & \multicolumn{6}{|c|}{$\mathrm{kg} \mathrm{ha}^{-1}$} & \multicolumn{2}{|c|}{$\mathrm{kg} \mathrm{kg}^{-1}$} & \multicolumn{2}{|c|}{$\mathrm{kg} \mathrm{ha}^{-1} \mathrm{~mm}^{-1}$} \\
\hline \multicolumn{11}{|l|}{ Intercropping } \\
\hline RT1 & 1,715 & 1,097 & 2,812 & 1,302 & 1,054 & 2,357 & 5.63 & 6.62 & 3.74 & 3.49 \\
\hline RT2 & 1,324 & 829 & 2,153 & 1,260 & 1,025 & 2,286 & 7.51 & 7.17 & 2.92 & 3.41 \\
\hline RT3 & 1,320 & 963 & 2,282 & 1,288 & 1,031 & 2,319 & 6.82 & 6.44 & 3.02 & 3.38 \\
\hline $\mathrm{CT}$ & 1,549 & 1,060 & 2,609 & 1,401 & 1,066 & 2,466 & 5.64 & 5.82 & 3.38 & 3.55 \\
\hline \multicolumn{11}{|l|}{ Monoculture } \\
\hline RT1 & - & 1,119 & 1,119 & 2,610 & - & 2,610 & 5.99 & 5.00 & 2.70 & 4.39 \\
\hline RT2 & - & 950 & 950 & 2,348 & - & 2,348 & 7.22 & 5.64 & 2.35 & 3.97 \\
\hline RT3 & - & 1,018 & 1,018 & 2,501 & - & 2,501 & 6.38 & 4.84 & 2.40 & 4.32 \\
\hline $\mathrm{CT}$ & - & 1,107 & 1,107 & 2,641 & - & 2,641 & 5.77 & 4.41 & 2.61 & 4.47 \\
\hline$p$ value ${ }^{\mathrm{b}}$ & $<0.01$ & $<0.01$ & $<0.01$ & $<0.01$ & $<0.01$ & $<0.01$ & $<0.01$ & $<0.01$ & $<0.01$ & $<0.01$ \\
\hline $\operatorname{LSD}(0.05)$ & 24 & 12 & 11 & 23 & 18 & 12 & 0.08 & 0.09 & 0.03 & 0.06 \\
\hline
\end{tabular}

$R T 1$ reduced tillage with stubble standing, $R T 2$ reduced tillage with stubble mulching, $R T 3$ reduced tillage with stubble incorporated in the soil, $C T$ conventional tillage without stubble retention

${ }^{\text {a }}$ Carbon emission was estimated using the soil respiration function (Zhai et al. 2011)

${ }^{\mathrm{b}}$ The $p$ value and the $\operatorname{LSD}(0.05)$ were for all the treatments in the column 


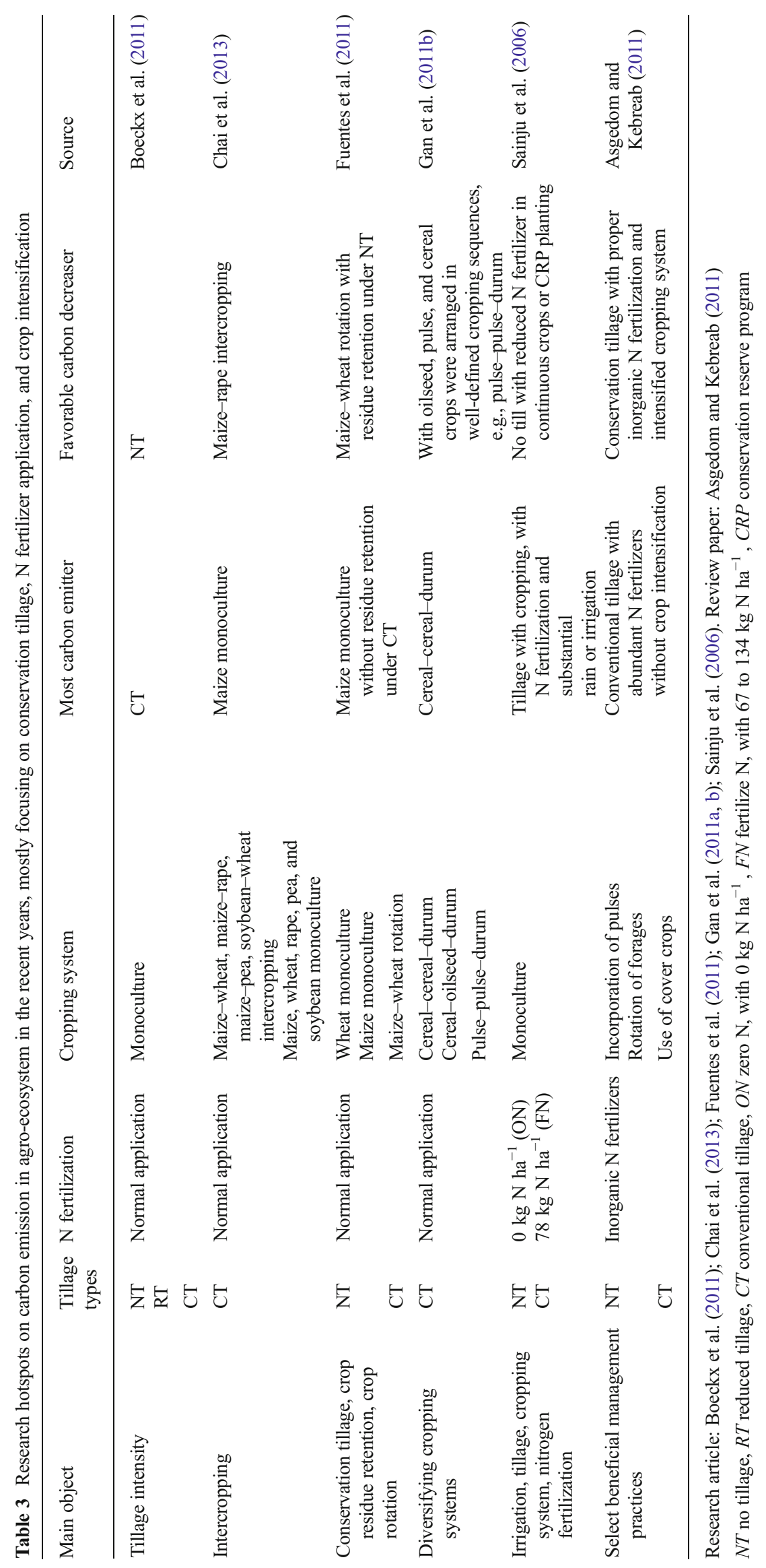


emission. In the present study, we used the term "carbon emission efficiency" to determine how much grain yield that was associated with per unit of carbon emission. The land equivalent ratios based on carbon emission efficiency for the four cropping systems were all higher than 2.0, indicating that intercropping not only saves land and increases yield, but also deeply restrains carbon emission. On average, wheat/maize intercropping produced $6.5 \mathrm{~kg}$ grain yield per kilogram of carbon emission or $36 \%$ greater than sole maize $\left(4.7 \mathrm{~kg} \mathrm{~kg}^{-1}\right)$ (Table 2). Reduced tillage with stubble mulching had a great influence on carbon emission efficiency, which contributed to the improved carbon emission efficiency by $18.7 \%$ (5.6 vs. $4.8 \mathrm{~kg} \mathrm{~kg}^{-1}$ ) for sole maize, $19.4 \%$ (7.2 vs. $\left.6.1 \mathrm{~kg} \mathrm{~kg}^{-1}\right)$ for sole wheat, and $19.2 \%\left(7.3\right.$ vs. $\left.6.2 \mathrm{~kg} \mathrm{~kg}^{-1}\right)$ for wheat/maize intercropping, as compared to the other stubble management options.

On average, sole wheat and sole maize under reduced tillage with stubble mulching increased carbon emission efficiency by 15 and $27 \%$ as compared to conventional sole wheat and sole maize, and $28 \%$ was increased by the favorable wheat/maize intercropping system annually; all were statistically significant (Table 2). Compared to conventional tillage, wheat monoculture, maize monoculture, and wheat/ maize intercropping under reduced tillage with stubble incorporated in the topsoil boosted carbon emission efficiency by 11,10 , and $16 \%$, respectively. Sole wheat under reduced tillage with stubble standing also played important role in enhancing carbon emission efficiency, which was increased by $13 \%$. Overall, stubble mulching based on reduced tillage was the optimum model in tillage management and residue retention treatments in promoting carbon emission efficiency.

\subsection{General discussion}

Common beneficial management practices that lead to $\mathrm{C}$ emission reduction from farmland are use of proper inorganic $\mathrm{N}$ fertilizers, cropping systems, e.g., diversifying cropping systems or crop intensification, and tillage practices, e.g., conservation tillage with or without applied crop residue retention including no-till and reduced tillage (Table 3). Increasing $\mathrm{N}$ fertilizer application for the sake of providing sufficient quantity of grains to meet the ever-growing population's needs has given rise to heavy carbon emissions. A well consideration of applying the $\mathrm{N}$ fertilizer at right rate, proper selection of the $\mathrm{N}$ sources, and timing application is highly recommended (Asgedom and Kebreab 2011). Cropping system is the major component of farmland, by managing farm in space and time. Adopting the diversified cropping systems in crop rotation is one of the promising strategies in mitigating GHG emissions from farming (Gan et al. 2011b). Besides, highly intensified cropping system such as maize-based intercropping is most effective in reducing carbon emission and establishing a sustainable cropping system (Chai et al. 2013).

Conservation tillage with decreased soil disturbance is most advantageous to reduce carbon emission. The less tillage intensity, the less soil respiratory $\mathrm{CO}_{2}-\mathrm{C}$ loss
Fig. 2 The conceptual figure of experimental design with linkages between issues, hypothesis, and results of this research

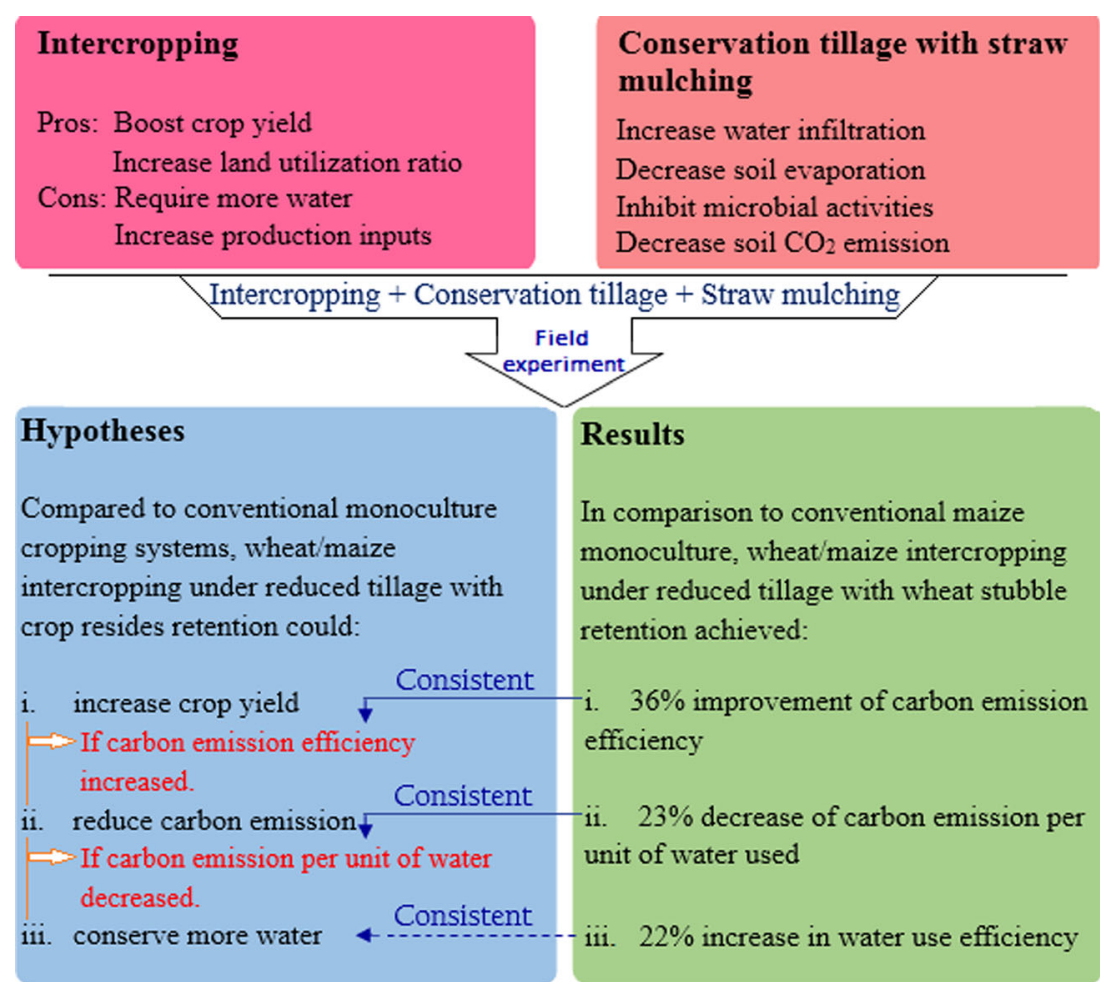


(Boeckx et al. 2011). Crop residue retention on the soil surface allows a barrier formed on the surface, helping reduce $\mathrm{CO}_{2}$ emission (Fuentes et al. 2011). The combination of crop residue retention with reduced tillage, sometimes, will enhance such an effect. In view of this, we took the two major components, i.e., cropping system and conservation tillage, into account. Then, we designed a field experiment by well considering the crop intensification, i.e., through wheat-maize intercropping and conservation tillage, through reduced tillage managements to meet the double advantages on carbon emission, which is new and novel. The design was formulated in a rational framework. When combined it with the results after the precise analysis, a conceptual figure was drawn to clearly describe the experimental design with linkages between issues, hypothesis, and results in a concise way (Fig. 2). Results of our study demonstrate that wheat/maize intercropping in combination with conservation tillage can significantly enhance carbon emission efficiency while lower carbon emission per unit of land and per unit of water. Thereby, we strongly recommend this favorable system to meet the side benefits of food security and climate change in arid areas.

\section{Conclusions}

Wheat/maize intercropping can effectively reduce soil respiration while increasing grain yield with improved water use efficiency significantly; this eventually leads to lower carbon emission per unit of water used and with higher carbon emission efficiency than monocultures. Reduced tillage combined with stubble mulching reduced carbon emission by 9,12 , and $10 \%$, respectively, for sole maize, sole wheat, and wheat/ maize intercropping. Wheat/maize intercropping under reduced tillage decreased carbon emissions per unit of water by $8 \%$ and improved carbon emission efficiency by $19 \%$ compared to conventional tillage. We conclude that wheat/ maize intercropping systems with reduced tillage and stubble mulching can be used to effectively lower carbon emissions per unit of land and per unit of water and enhance carbon emission efficiency in arid areas. In the long run, this cropping system, when managed well, can be adapted in a wide range of environments to capture the large benefit of food security while mitigating climate change.

Acknowledgments We are grateful to the research grants provided by the National Key Technology R\&D Program (granted number 2012BAD14B10), the National Natural Science Fund (granted number 31360323), the Special Fund for Agro-scientific Research in the Public Interest (granted number 201103001), and the Excellent Youth Foundation of Gansu Scientific Committee (1111RJDA006).

\section{References}

Alletto L, Coquet Y, Benoit P, Heddadj D, Barriuso E (2010) Tillage management effects on pesticide fate in soils. A review. Agron Sustain Dev 30(2). doi:10.1051/agro/2009018

Asgedom H, Kebreab E (2011) Beneficial management practices and mitigation of greenhouse gas emissions in the agriculture of the Canadian Prairie: a review. Agron Sustain Dev 31(3):433-451. doi:10.1007/s13593-011-0016-2

Beedy TL, Snapp SS, Akinnifesi FK, Sileshi GW (2010) Impact of Gliricidia sepium intercropping on soil organic matter fractions in a maize-based cropping system. Agric Ecosyst Environ 138(3-4): 139-146. doi:10.1016/j.agee.2010.04.008

Boeckx P, Van Nieuland K, Van Cleemput O (2011) Short-term effect of tillage intensity on $\mathrm{N}_{2} \mathrm{O}$ and $\mathrm{CO}_{2}$ emissions. Agron Sustain Dev 31(3):453-461. doi:10.1007/s13593-011-0001-9

Chai Q, Qin AZ, Gan YT, Yu AZ (2013) Higher yield and lower carbon emission by intercropping maize with rape, pea, and wheat in arid irrigation areas. Agron Sustain Dev 34(34):535-543. doi:10.1007/ s13593-013-0161-x

Dyer L, Oelbermann M, Echarte L (2012) Soil carbon dioxide and nitrous oxide emissions during the growing season from temperate maizesoybean intercrops. J Plant Nutr Soil Sci 175(3):394-400

Elder JW, Lal R (2008) Tillage effects on gaseous emissions from an intensively farmed organic soil in North Central Ohio. Soil Tillage Res 98(1):45-55

Fan ZL, Chai Q, Huang GB, Yu AZ, Huang P, Yang CH, Tao ZQ, Liu HL (2012) Yield and water consumption characteristics of wheat/maize intercropping with reduced tillage in an Oasis region. Eur J Agron 25121:1-7. doi:10.1016/j.eja.2012.10.010

FAO/UNESCO (1988) Soil map of the world: revised legend/prepared by the Food and Agriculture Organization of the United Nations. World soil resources report. Unesco

Fedoroff NV, Battisti DS, Beachy RN, Cooper PJM, Fischhoff DA, Hodges CN, Knauf VC, Lobell D, Mazur BJ, Molden D, Reynolds MP, Ronald PC, Rosegrant MW, Sanchez PA, Vonshak A, Zhu JK (2010) Radically rethinking agriculture for the 21st century. Science 327(5967):833-834. doi:10.1126/science.1186834

Fuentes M, Hidalgo C, Etchevers J, De León F, Guerrero A, Dendooven L, Verhulst N, Govaerts B (2011) Conservation agriculture, increased organic carbon in the top-soil macro-aggregates and reduced soil $\mathrm{CO}_{2}$ emissions. Plant Soil 355(1-2):183-197. doi:10.1007/ s11104-011-1092-4

Gan YT, Liang C, Huang GB, Malhi S, Brandt S, Katepa-Mupondwa F (2011a) Carbon footprint of canola and mustard is a function of the rate of N fertilizer. Int J Life Cycle Asses 17(1):58-68. doi:10.1007/ s11367-011-0337-z

Gan YT, Liang C, Wang XY, McConkey B (2011b) Lowering carbon footprint of durum wheat by diversifying cropping systems. Field Crop Res 122(3):199-206. doi:10.1016/j.fcr.2011.03.020

Gan YT, Liang C, Campbell CA, Zentner RP, Lemke RL, Wang H, Yang C (2012) Carbon footprint of spring wheat in response to fallow frequency and soil carbon changes over 25 years on the semiarid Canadian prairie. Eur J Agron 43:175-184. doi:10.1016/j.eja.2012. 07.004

Gan YT, Siddique KHM, Turner NC, Li XG, Niu JY, Yang C, Liu LP, Chai Q (2013) Chapter seven — ridge-furrow mulching systems - an innovative technique for boosting crop productivity in semiarid rainfed environments. In: Donald LS (ed) Advances in agronomy, vol 118. Academic Press, pp 429-476. doi:10.1016/B978-0-12405942-9.00007-4

Grace J, Rayment M (2000) Respiration in the balance. Nature 404:819 820

Lal R, Griffin M, Apt J, Lave L, Morgan MG (2004) Ecology. Managing soil carbon. Science 304(5669):393. doi:10.1126/science.1093079 
Li H, Qiu JJ, Wang LG (2008) Characterization of farm land soil respiration and modeling analysis of contribution of root respiration. Trans Chin Soc Agr Eng 24(4):14-20. doi:10.3321/j.issn:10026819.2008.04.003

Mueller ND, Gerber JS, Johnston M, Ray DK, Ramankutty N, Foley JA (2012) Closing yield gaps through nutrient and water management. Nature 490(7419):254-257. doi:10.1038/ nature 11420

Qin AZ, Huang GB, Chai Q, Yu AZ, Huang P (2013) Grain yield and soil respiratory response to intercropping systems on arid land. Field Crop Res 144:1-10. doi:10.1016/j.fcr.2012.12.005

Raich JW, Tufekcioglu A (2000) Vegetation and soil respiration: correlations and controls. Biogeochemistry 48:71-90

Sainju UM, Jabro JD, Stevens WB (2006) Soil carbon dioxide emission and carbon content as affected by irrigation, tillage, cropping system, and nitrogen fertilization. J Environ Qual 37:98-106. doi: $10.2134 /$ jeq2006.0392

Schlesinger WH, Andrews JA (2000) Soil respiration and the global carbon cycle. Biogeochemistry 48:7-20

USDA-SCS (1972) National engineering handbook. Soil Conservation Service. USDA, Washington

Yang CH, Huang GB, Chai Q, Luo ZX (2011) Water use and yield of wheat/maize intercropping under alternate irrigation in the oasis field of northwest China. Field Crop Res 124:426-432. doi:10. 1016/j.fcr.2011.07.013

Zhai LM, Liu HB, Zhang JZ, Huang J, Wang BR (2011) Long-term application of organic manure and mineral fertilizer on $\mathrm{N}_{2} \mathrm{O}$ and $\mathrm{CO}_{2}$ emissions in a red soil from cultivated maize-wheat rotation in China. J Integr Agr 10(11):1748-1757. doi:10.1016/s16712927(11)60174-0 